\title{
Investigation of the relationship between Abdominal Aortic Calcified Plaques deter- mined by multidetector computed tomogra- phy (MDCT) and Body Mass Index (BMI)
}

\section{Abdominal Aort Kalsifik plak oluşumu ile Vücut Kitle İndeksi arasındaki ilişkinin MDCT ile araștırılması}

\author{
Duran Efe ${ }^{1}$, Türker Acar ${ }^{1}$, *Fatih Aygün ${ }^{2}$, Melda Yıldız ${ }^{1}$, Kazım Gemici ${ }^{3}$ \\ ${ }^{1}$ Department of Radiology, Mevlana University School of Medicine, Konya, Turkey \\ ${ }^{2}$ Department of Cardiovascular Surgery, Başkent University Konya Medical and Research Center, Konya, Turkey \\ ${ }^{3}$ Department of General Surgery, Mevlana University School of Medicine, Konya, Turkey \\ Corresponding author: Dr. Fatih Aygün, Kalp Damar Cerrahisi Anabilim Dalı, Başkent Üniversitesi Konya Tıp ve \\ Araştırma Merkezi, TR-42080, Konya, Türkiye \\ E-mail: fatihaygun@ttmail.com \\ Received/Accepted: January 12, 2015/September 11, 2015 \\ Conflict of interest: There is not a conflict of interest. \\ *Acknowledgements: We would like to thank Assoc. Prof. Ismail Keskin for his dedicated contributions during prepara- \\ tion of statistics (Department of Biometry and Genetics, Selçuk University)
}

\section{SUMMARY}

Objective: Potential correlation between abdominal aortic atherosclerosis measured by multidetector computed tomography (MDCT) and body mass index (BMI) is investigated in this presented study.

Method: The presented study includes 228 patients between July 2013 and January 2014 in our clinic. Calcium scores of abdominal aortic calcified plaques (AaCs) between celiac trunk and iliac bifurcation in axial sections were measured as Agatston units (AU.). Following the abdominal computed tomography (CT) scans, all patient's heights and weights were obtained from medical reports. Their body mass indexes (BMI) were calculated by dividing these two variables. Patients were then grouped according to World Health Organization Expert Committee on Physical Status. BMIs under $25 \mathrm{~kg} / \mathrm{m}^{2}$ were categorized as normal weighted group (Group 1), BMIs between 25 $29.9 \mathrm{~kg} / \mathrm{m}^{2}$ were grouped as overweighted (Group 2), and BMIs equal or over $30 \mathrm{~kg} / \mathrm{m}^{2}$ were accepted as obese group (Group 3).

Results: Mean BMIs - AaCs in Group 1, 2, and 3 were found to be $22.3 \pm 1.6-254 \pm 597$ AU, $27.4 \pm 1.4-244.5 \pm 496.7$ AU, $33.4 \pm 2.6$ - 368.2 \pm 604.5 AU, respectively.

Conclusions: According to correlation analysis, no significant correlation was observed between $\mathrm{BMI}$ and $\mathrm{AaCs}$ in these subgroups.

Keywords: Multidedector computed tomography, body mass index, arteriosclerosis, calcification

\section{ÖZET}

Amaç: Bu çalışmada, multidedektörlü BT (MDBT) ile ölçülmüş abdominal aort aterosklerozu ve vücut kitle indeksi arasında olası ilişki araştırıldı.

Yöntem: Çalışmamız kliniğimizde temmuz 2013 ve ocak 2014 tarihleri arasında kontrassız abdominal BT çekilen 228 kişiyi içermektedir. BT aksiyel kesitlerde çöliyak trunkus ve iliak bifurkasyon arasında abdominal aort kalsifik plaklarının kalsiyum skorlanı (AaCs) Agatston üniti (a.u) olarak ölçüldü Tüm hastalarımızın abdominal BT çekim sonrasında, boy (İnsan baskülü, NAN TARTI AŞ, Türkiye) ve kiloları (TANITA Body Composition Analyzer, TANITA Corporation, Japan) ölçüldü. Vücut kitle indeksleri hesaplandı. BMI'i 25 kilogram $(\mathrm{kg}) /$ metrekare $\left(\mathrm{m}^{2}\right)$ nin altında olanlar (BMI $<25 \mathrm{~kg} / \mathrm{m}^{2}$ ) normal kilolu (Grup 1), $25 \mathrm{~kg} / \mathrm{m}^{2}$ ile 29,9 kg/m² arasinda olanlar $\left(25 \mathrm{~kg} / \mathrm{m}^{2} \leq \mathrm{BMI}<29,9 \mathrm{~kg} / \mathrm{m}^{2}\right.$ ) aşırı kilolu (Grup 2), $30 \mathrm{~kg} / \mathrm{m}^{2}$ ve üstünde olanlar (30 
$\mathrm{kg} / \mathrm{m}^{2} \leq \mathrm{BMI}$ ) obez (Grup 3) kabul edildi.

Bulgular: Çalışmaya katılan tüm bireylerin yaş dağılımı; minimum(min) 20 y1l (y), maksimum(max) 87 yıldır (ortalama \pm standart sapma 44,1 $\pm 14,2$ y). Bu kișilerin 150'si (\%65,8) erkek, 78'i $(\% 34,2)$ kadındır. Çalışmaya katılanlar arasında; Aortik kalsiyum skoru (AaCs) min 0 au, max 2201 au (ortalama \pm standart sapma 286,3 \pm 561,5), BMI min 18, max 41 (ortalama \pm standart sapma 27,9 $\pm 4,7$ ) olarak tespit edildi.

Sonuç: BMI grupları ile AaCs arasında korelasyon analizi yapıldı. Anlamlı ilişki tespit edilmedi. Anahtar sözcükler: Multidedektörlü bilgisayarlı tomografi, vücut kitle indeksi, arteriyoskleroz, kalsifikasyon

\section{INTRODUCTION}

The rates of being over weighted and obesity are gradually increasing in developed countries ${ }^{1-3}$. It is well known that obesity is related with higher atherosclerotic plaques, hypertension, diabetes mellitus, cardiovascular diseases (CVDs) and metabolic risk factors $^{4-7}$. It has been reported in some studies that elevation in body mass index (BMI) effects CVDs, cancer, and other mortality risks particularly in middle aged and elderly people $\mathrm{e}^{8-10}$. Obesity leads to major vascular dysfunctions through metabolic disorders, inflammatory pathways, obstructive sleep apnea or other mechanisms $^{11,12}$. It has been shown in some studies conducted with lateral lumbar radiography that calcified aortic plaque development is an independent predictor in the CVDs and heart failure ${ }^{13}$.

The aim of the presented study is to correlate the abdominal aortic calcific plaque burden (an indicative of atherosclerosis) measured by Multidetector CT (MDCT) with BMI.

\section{MATERIAL AND METHODS}

228 patients who underwent unenhanced abdominal CT between July 2013 and January 2014 in our clinic were enrolled in this study. Data was collected retrospectively and this study was approved by our departmental and institutional review boards. Following the abdominal CT scans of all patients, their heights (human weighing scale, Nan Tarti Company, Turkey) and weights (Tanita Body Composition Analyzer, Tanita Corporation, Japan) were obtained from medical records. Each patient's BMIs were calculated by dividing weight $(\mathrm{kg})$ to square meters $\left(\mathrm{m}^{2}\right)$ of height. Baseline BMIs were re-categorized using the classification of the World Health Organization Expert Committee on Physical Status (14). BMIs under $25 \mathrm{~kg} / \mathrm{m}^{2}$
$\left(\mathrm{BMI}<25 \mathrm{~kg} / \mathrm{m}^{2}\right)$ were considered to be normal weighted population and categorized as (Group 1), BMIs between 25 $\mathrm{kg} / \mathrm{m}^{2}$ and $29.9 \mathrm{~kg} / \mathrm{m}^{2} \quad\left(25 \mathrm{~kg} / \mathrm{m}^{2}\right.$ $\leq \mathrm{BMI}<29.9 \mathrm{~kg} / \mathrm{m}^{2}$ ) were categorized as overweighted group (Group 2), and BMIs equal or over $30 \mathrm{~kg} / \mathrm{m}^{2}\left(30 \mathrm{~kg} / \mathrm{m}^{2} \leq \mathrm{BMI}\right)$ were grouped as obese group (Group 3 ).

All patients were evaluated from medical archive for possible additional diseased including diabetes mellitus, hypertension, dyslipidemia. Smoking history as a risk factor was also questioned for each patients.

Unenhanced abdominal CT scans were performed at an uninterrupted $0.6 \mathrm{~mm}$ slice thickness extending from subdiaphragmatic level to symphysis pubis. A multidetector CT device (Somatom Sensation 64, Siemens, Forchheim, Germany) was used for tomographic evaluation.

The scan parameters were $64 \times 0.625 \mathrm{~mm}$ collimation, tube voltage $100-120 \mathrm{mV}$, and effective mA 350-780 mA. Calcium scores of abdominal aortic calcified plaques (AaCs) between celiac trunk and iliac bifurcation in axial CT sections were measured as Agatston units (A.U.) (Figure1). Each calcium scores was measured using a dedicated software (Syngo CaScore, Siemens, Forchheim, Germany, Agatston scoring method) commercially available ${ }^{14}$.

\section{Statistical analysis}

Statistical analyses were performed with SPSS ${ }^{\circledR}$ for Windows software (version 15.00, Chicago, IL). Statistical significance of nonparametric data between groups was analyzed by Pearson Chi-square test. Parametric data was expressed as minimum, maximum, mean \pm standard deviation, statistical significance of parametric data between groups were examined using independent student $t$ test. The relationship between AaCs of groups was investigated 
using correlation analysis. The level of the significance was taken as $\mathrm{p}<0.05$.

\section{RESULTS}

The age distribution of the patients in the study was; minimum (min) 20 (y) and maximum (max) 87 (mean \pm standard deviation $44.1 \pm 14.2 \mathrm{y})$. One hundred and fifty of these patients $(65.8 \%)$ were male, wheas 78 of them $(34.2 \%)$ are females. The number and persentages of patients with diabetes mellitus was $32(14 \%)$, hypertension (HT) $60 \quad(26.3 \%)$, and dyslipidemia $62(27.2 \%)$, respectively. The number of smokers was 92 (40.4\%). Among the participants of the study, the aortic calcium score (AaCs) was found to be min 0 au, $\max 2201$ au (mean \pm standard deviation $286.3 \pm 561.5$ ), and the BMI was found to be min 18, max 41 (mean \pm standard deviation $27.9 \pm 4.7$ ) (Table 1).

Table 1: Subject characteristics.

\begin{tabular}{l|lll}
\hline & Group 1 & Group 2 & Group 3 \\
\cline { 2 - 4 } & $(\mathbf{n = 6 4 )}$ & $\mathbf{( n = 9 2 )}$ & $(\mathbf{n = 7 2})$ \\
\hline Age $( \pm$ SD) & $37.5 \pm 15.9$ & $44.6 \pm 12.9$ & $49.4 \pm 12$ \\
Gender (male) & $42(65.6 \%)$ & $68(73.9 \%)$ & $40(55.6 \%)$ \\
Diabetes mellitus (Type 2) & $8(12.5 \%)$ & $14(15.2 \%)$ & $10(13.9 \%)$ \\
Hypertension & $8(12.5 \%)$ & $26(28.3 \%)$ & $26(36.1 \%)$ \\
Dislipidemia & $10(15.6 \%)$ & $24(26.1 \%)$ & $28(38.9 \%)$ \\
Smoking & $24(37.5 \%)$ & $44(47.8 \%)$ & $24(33.3 \%)$ \\
BMI & $22.3 \pm 1.6$ & $27.4 \pm 1.4$ & $33.4 \pm 2.6$ \\
Abdominal Aortic Calcium Scoring (AaCs) (au) ( \pm SD) & $254 \pm 597$ & $244.5 \pm 496.7$ & $368.2 \pm 604.5$ \\
BMI: Body Mass Index, SD: Standart deviation. & & &
\end{tabular}

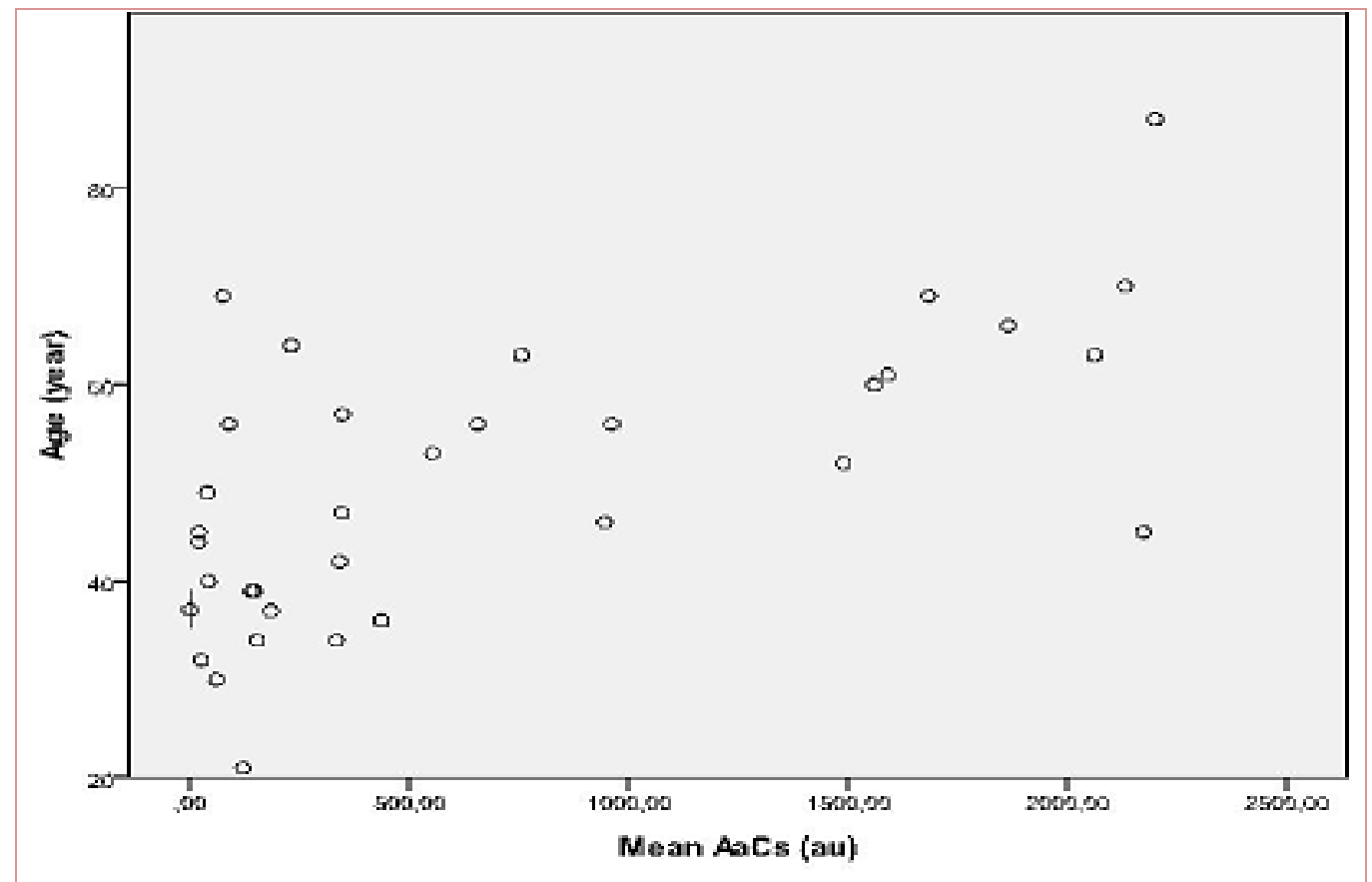

Figure 1: Mean AaCS according to age in male patients. 


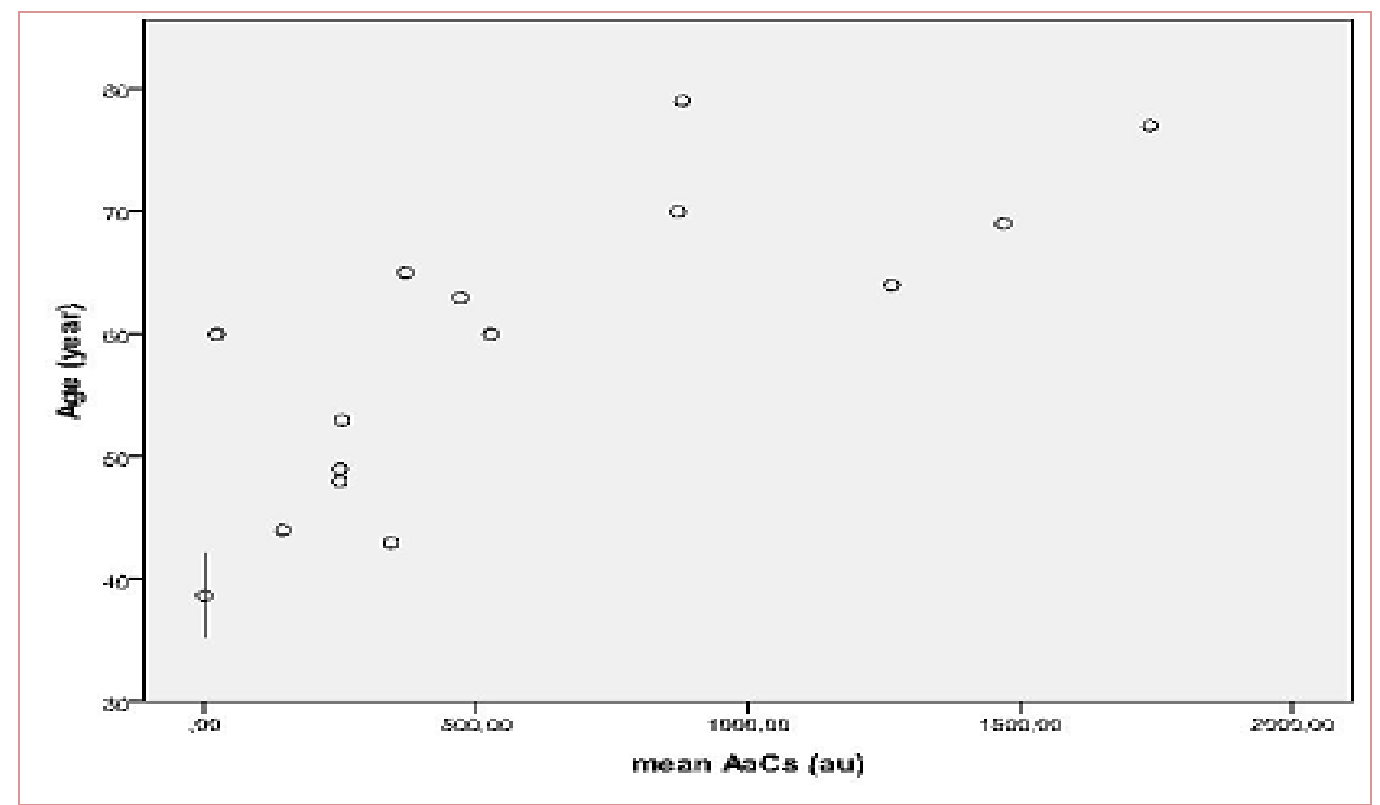

Figure 2: Mean AaCS according to age in female patients.

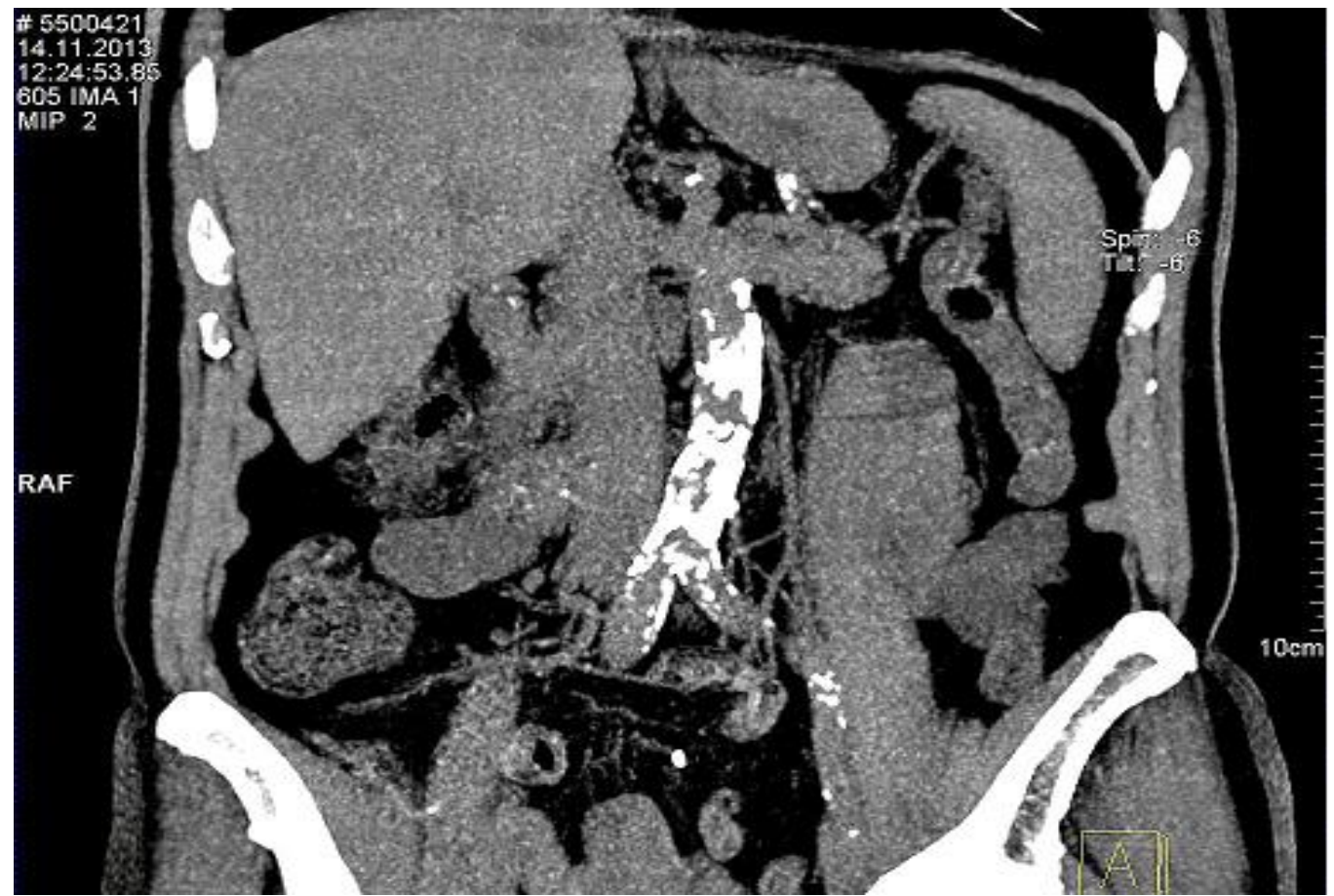

Figure 3: Coronal CT section shows widespread calcified plaques in the abdominal aorta.

Mean BMI and AaCs in Group 1 were found to be $22.3 \pm 1.6$ and $254 \pm 597 \mathrm{AU}$. In the males of Group 1; Age, BMI, and AaCs means \pm standard deviations were $40.9 \pm 17.5 \mathrm{y}, 22.7 \pm 1.6$, and $370.8 \pm$ 708.4 AU respectively. Eighteen (42.9\%) patients had smoking, 8 (19\%) had hypertension, $10(23.8 \%)$ had dyslipidemia, and $8(19 \%)$ had diabetes mellitus history respectively in the males of Group 1.
In the females of Group 1; Age, BMI, and AaCs means \pm standard deviations were $30.9 \pm 9.6 \mathrm{y}, 21.6 \pm 1.5$, and $31.1 \pm 100.9$ AU respectively. Six (27.3\%) had smoking history, but none has hypertension, dyslipidemia or diabetes mellitus history in the female counterpart of Group 1. Mean $\mathrm{BMI}$ and $\mathrm{AaCs}$ in Group 2 were found to be $27.4 \pm 1.4$ and $244.5 \pm 496.7 \mathrm{AU}$. In the males of Group 2; Age, BMI, and AaCs 
means \pm standard deviations were $42.5 \pm$ $11.8 \mathrm{y}, 27.4 \pm 1.4$, and $251.7 \pm 523.3 \mathrm{AU}$, respectively. Thirty-four $(50 \%)$ patients had smoking, 14 (20.6\%) had hypertension, $20(29.4 \%)$ had dyslipidemia, and 12 $(17.6 \%)$ had diabetes mellitus history respectively in the males of Group 2.

In the females of Group 2; Age, BMI, and $\mathrm{AaCs}$ means \pm standard deviations were $50.3 \pm 14.4 \mathrm{y}, 27.5 \pm 1.2$, and $224.2 \pm$ 421.5 AU, respectively. Ten $(41.7 \%)$ had smoking, $12(50 \%)$ had hypertension, 4 $(16,7 \%)$ had dyslipidemia, and $2(8.3 \%)$ had diabetes mellitus history respectively in the females of Group 2. Mean BMI and $\mathrm{AaCs}$ in Group 3 were found to be $33.4 \pm 2.6$ and $368.2 \pm 604.5 \mathrm{AU}$. In the males of Group3; Age, BMI, and AaCs means \pm standard deviations were $45.6 \pm$ $10.4 \mathrm{y}, 33.4 \pm 3$, and $372.2 \pm 663.3 \mathrm{AU}$ respectively. Sixteen $(40 \%)$ had smoking, $10(25 \%)$ had hypertension, $14(35 \%)$ had dyslipidemia, and 8 (20\%) had diabetes mellitus history respectively in the males of Group 3.

In the females of Group 3; Age, BMI, and $\mathrm{AaCs}$ means \pm standard deviations were $54.1 \pm 12.3 \mathrm{y}, 33.4 \pm 1.9$, and $363.3 \pm$ 532.4 AU respectively. Six (25\%) had smoking, $16(50 \%)$ had hypertension, 14 (43.8\%) had dyslipidemia, and 2 (6.3\%) had diabetes mellitus history respectively in the females of Group 3.

Mean AaCs accoding to age of male patients are demonstrated in Figure 1 and females are shown in Figure 2.

\section{DISCUSSION}

The relationship between BMI and AaCs which is regarded as atherosclerosis indicator was investigated in our study. No relation was observed between BMI and $\mathrm{AaCs}$. Mean BMI and AaCs in males were found to be $27.7 \pm 4.4$ and $317.2 \pm 616.4$ $\mathrm{AU}$, respectively, and on the other hand these aforementioned variables in females were $28.2 \pm 5.1$ and $226.83 \pm 434.3 \mathrm{AU}$, respectively. The differences between males and females in terms of BMI and $\mathrm{AaCs}$ were found to be statistically insignificant ( $\mathrm{p}=0.395$ for $\mathrm{BMI}$; $\mathrm{p}=0.250$ for $\mathrm{AaCs}$, respectively).

Coronary and extracoronary arterial calci- fied plaques are considered to be indicator of atherosclerosis and subclinical cardiovascular disease $\mathrm{e}^{15-17}$. In a study in which coronary arteries and peripheral arteries were examined, $47 \%$ of females and $70 \%$ of males younger than 50 years were found to have calcific plaques ${ }^{18}$.In contrast to this aforementioned literature coronary and other peripheral arteries were not included in our study, but calcified aortic plaques were identified in $16.7 \%$ of females and $30.9 \%$ of males younger than 50 years.

In coronary artery studies, the mean age of males were found to be 10 to 15 years younger than females who have calcified plaque in coronary arteries. In accordance with coronary arteries, the mean age of females diagnosed with plaque in the abdominal aorta was found to be older than male counterparts (Mean female age: 60.2 \pm 11.3 , and mean male age: $50.3 \pm 14.2$ ) in the presented study. The reason as to why atherosclerosis occurs at older ages in females compared to males can be explained with the protective effects of sex hormones $^{19}$. In some earlier studies conducted with lung radiography, a significant relation was found between aortic arch calcification and age, hypertension and smoking while it was found to be inversely relation with BMI. This phenomenon is called obesity paradox ${ }^{20-23}$. In our study, which was conducted with MDCT, significant relationship was observed between BMI and male gender $(\mathrm{p}=0.049)$, hypertension $(\mathrm{p}=0.007)$, dyslipidemia $(\mathrm{p}=0.009)$ and age $(\mathrm{p}<0.001)$. Abdominal aortic calcified plaque development revealed significant relation with hypertension $(\mathrm{p}<0.001)$, dyslipidemia $(p<0.001)$ and diabetes mellitus $(\mathrm{p}<0.001)$.

Although in some studies inverse relation was found between BMI and unstable plaque prevalence (obesity paradox), no positively or negatively significant relationship was observed between BMI and abdominal aortic calcified plaque development according to the results of our study. We think that limited number of the cases in this presented study can be an explanation. We believe that our results should be supported with more extensive epidemiological and geographical studies.

The number of cases in our study was rela- 
tively low; which was the main limitation of the presented study. Besides, all of the cases were from the same geographical region and race, so they may not precisely reflect other ethnic groups or different geographical regions. Lastly, only the calcified plaques in the abdominal aorta were investigated in our study, so our results did not include the correlation between soft plaque development and BMI.

\section{REFERENCES}

1. Flegal KM, Carroll MD, Kuczmarski RJ. Overweight and obesity in the United States: prevalence and trends. Int J Obes Relat Metab Disord 1998; 22: 39-47.

2. Flegal KM, Carroll MD, Ogden CL. Prevalence and trends in obesity among US adults. JAMA 2002; 2881723-7.

3. Ogden CL, Carroll MD, Curtin LR. Prevalence of overweight and obesity in the United States. JAMA 2006; 295: 1549-55.

4. Wong ND, Hsu JC, Detrano RC. Coronary artery calcium evaluation by electron beam computed tomography and its relation to new cardiovascular events. Am J Cardiol 2000; 86: 495-8.

5. Arad Y, Spadaro LA, Goodman K. Predictive value of electron beam computed tomography of the coronary arteries. 19-month follow-up of 1173 asymptomatic subjects. Circulation 1996; 93: 1951-3.

6. Detrano R, Guerci AD, Carr JJ. Coronary calcium as a predictor of coronary events in four racial or ethnic groups. N Engl J Med 2008; 358: 1336-45.

7. Poirier P, Giles TD, Bray GA. Obesity and cardiovascular disease: pathophysiology, evaluation and effect of weight loss: an update of the 1997 American Heart Association scientific statement on obesity and heart disease from the Obesity Committee of the Council on Nutrition, physical activity, and metabolism. Circulation 2006; 113: 898-918.

8. Rosengren A, Wedel H, Wilhelmsen L. Body weight and weight gain during adult life in men in relation to coronary heart disease and mortality. A prospective population study. Eur Heart J 1999; 20: 269-77.

9. Breeze E, Clarke R, Shipley MJ. Cause-specifi mortality in old age in relation to body mass index in middle age and in old age: followup of the Whitehall cohort of male civil servants. Int $\mathrm{J}$ Epidemiol 2006; 35: 169-78.

10. Bamia C, Halkjaer J, Lagiou $P$. Weight change in later life and risk of death amongst the elderly: the European prospective investigation into cancer and nutrition-elderly network on ageing and health study. J Intern Med 2010; 268: 133-44.

11. Jelic S, Bartels MN, Mateika JH. Arterial stiffness increases during obstructive sleep apneas. Sleep 2002; 25: 850-5.

12. Hall JE. The kidney, hypertension, and obesity. Hypertension 2003; 41: 625-33.

13. Walsh CR, Cupples LA, Levy D. Abdominal aortic calcific deposits are associated with increased risk for congestive heart failure: the Framingham Heart Study. Am Heart J 2002; 144: 733-9.

14. World Health Organization. Physical status: the use and interpretation of anthropometry. Report of a WHO Expert Committee.In: World Health Organization technical report series 1995; 854: 1452.

15. Wexler L, Brundage B, Crouse J. Coronary artery calcification: pathophysiology, epidemiology, imaging methods, and clinical implications: a statement for health professionals from the American Heart Association Writing Group. Circulation 1996; 94: 1175-92.

16. Rumberger JA, Simons DB, Fitzpatrick LA. Coronary artery calcium area by electron-beam computed tomography and coronary atherosclerotic plaque area: a histopathologic correlative study. Circulation 1995; 92: 2157-62. 
17. Simon A, Giral P, Levenson J. Extracoronary atherosclerotic plaque at multiple sites and total coronary calcification deposit in asymptomatic men: association with coronary risk profile. Circulation 1995; 92: 1414-21.

18. Allison MA, Criqui MH, Wright CM: Patterns and risk factors for systemic calcified atherosclerosis. Arterioscler Thromb Vasc Biol 2004; 24: 331-6.

19. Hoff JA, Chomka EV, Krainik AJ. Age and gender distributions of coronary artery calcium detected by electron beam tomography in 35,246 adults. Am J Cardiol 2001; 87: 1335-9.

20. Teale C, Romaniuk C, Mulley G. Calcification on chest radiographs: the association with age. Age Ageing 1989; 18: 333-6.

21. Gorich J, Zuna I, Merle M. Aortic calcification in CT: correlation with risk factors and cardiovascular diseases. Radiologe 1989; 29: 614.

22. Iribarren C, Sidney S, Sternfeld B. Calcification of the aortic arch: risk factors and association with coronary heart disease, stroke, and peripheral vascular disease. JAMA 2000; 283: 2810-5.

23. Pacchioni A, Rossi A, Benfari G. A higher body mass index is associated with reduced prevalence of unstable atherosclerotic plaque: a possible explanation of the obesity paradox.Int J Cardiol 2013; 168: 2912-3. 